\title{
Ficções sociológicas: três estudos de interpretação literária
}

\author{
João Daniel Cardoso de Lima
}

Curso: Mestrado em Sociologia

Data da defesa: 9 de julho de 2009

Orientador: Prof. Dr. Luis Augusto Sarmento Cavalcanti de Gusmão

\section{Resumo}

Este é um estudo de Epistemologia das Ciências Sociais. Mais especificamente, é uma ilustração de efeitos destrutivos, sobre 
a investigação social empírica, acarretados pelo compromisso com teorias sociológicas e com uma tentativa de ruptura com o universo conceitual de senso comum. Tal exercício é aqui levado a cabo, sobretudo, pela comparação entre interpretações literárias orientadas por teorias sociológicas e interpretações "tradicionais", isto é, em continuidade com o repertório linguístico-interpretativo de senso comum.

A dissertação se desenvolve em três capítulos relativamente independentes. O primeiro avalia a análise de A educação sentimental, de Gustave Flaubert, feita por Pierre Bourdieu (1996); o segundo, o estudo de Oliver Twist e Bleak house, de Charles Dickens, por D. A. Miller (1988); e o terceiro, a análise de Lord Jim e Nostromo, de Joseph Conrad, por Fredric Jameson (1981).

O que une os três casos analisados é o abuso do argumento analógico, onde se confunde a aproximação metafórica de realidades distintas com a demonstração de elos empíricos. Os três críticos compartilham também o recurso a estratégias de imunização de possíveis contra-argumentos, drenando suas hipóteses de conteúdo empírico. No caso de Bourdieu, no entanto, algumas teses não são completamente infalseáveis (sendo, nesses casos, simplesmente, falsas). Não é o que se constata em Miller e Jameson: estes críticos não tratam de nada observável, recorrendo invariavelmente à imputação especulativa de sentidos ocultos, inverificáveis, às obras que analisam.

As interpretações "tradicionais" invocadas servem, por sua vez, não só na identificação de incorreções factuais (quando há hipóteses com conteúdo empírico), mas também no grifo de distorções dos enredos literários, derivadas da aplicação forçada de teorias sociológicas.

Palavras-chave: Literatura; Pierre Bourdieu; D. A. Miller; Michel Foucault; Fredric Jameson. 